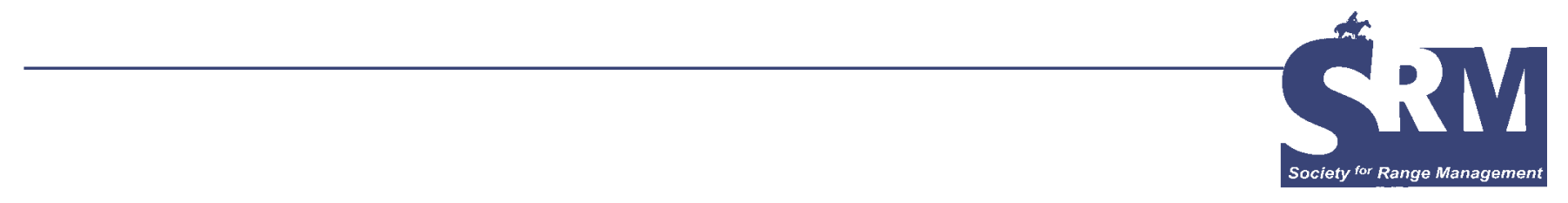

\title{
Aspen Decline, Aspen Chemistry, and Elk Herbivory: Are They Linked?
}

\section{Aspen chemical ecology can inform the discussion of aspen decline in the West}

\section{By Stuart C. Wooley, Scott Walker, Jason Vernon, and Richard L. Lindroth}

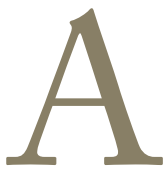

spen (Populus tremuloides) provides important habitat for mammals and birds ${ }^{1-3}$, improves water retention in watersheds, ${ }^{4}$ and has high aesthetic appeal in autumn. However, the amount and quality of aspen cover in the West has been declining for many years. For example, aspen cover in the Dixie and Fishlake National forests in Utah has decreased by more than $60 \%$ from historic levels, and in the Uinta National Forest aspen cover has been reduced by nearly $40 \%{ }^{5}$. The decline is so severe that Mueggler ${ }^{4}$ suggested that aspen-dominated woodlands might shift to shrubgrasslands under current management practices. The decline is disturbing because in the western United States, aspens are second only to riparian areas in terms of biodiversity. ${ }^{1}$

Why is aspen declining in the West? Climate change, reduced fire intervals, and browsing by deer, elk, and cattle $13,5,6$ all have been suggested as contributing to the decline of aspen. Aspen is a highly palatable browse for $\mathrm{elk}^{1,7,8}$ and many researchers suggest that herbivory by both livestock and wild ungulates are the main causes of aspen decline.

Some investigators have suggested that western aspen might be "doomed" because of the magnitude and historic trends of aspen decline. In the Manti-LaSal National Forest, aspen used by either cattle or wildlife showed a reduction of $30 \%$ in the number of sprouts between 1991 and $1992 .{ }^{6}$ In areas used by both cattle and wildlife, the number of aspen

This article has been peer-reviewed. sprouts decreased by 59\%. Losing almost two-thirds of the population in $1 \mathrm{yr}$ to ungulate herbivory does suggest that long-term aspen regeneration might indeed be doomed.

After evaluating historical and current data on aspen stands in and around exclosures in Utah, Kay and Bartos ${ }^{6}$ concluded that ungulate (wild and domestic) herbivory was the most likely explanation for aspen decline in south-central Utah. Results from other studies performed on elk-aspen interactions in the western United States ${ }^{1,10-12}$ tend to support those conclusions, as do results from studies on willows, ${ }^{2,13}$ but see papers by Singer and coworkers. ${ }^{14,15}$ Finally, in speaking with managers and other stakeholders, we found that all aspen are considered to be equally susceptible to herbivory.

Aspen regeneration is perceived to be at the mercy of elk and cattle, but observations by scientists working in the Fishlake National Forest in central Utah indicate that all aspen clones are not equally susceptible to elk herbivory. In fact, at four sites on Monroe Mountain above Koosharem, Utah, several pairs of aspen clones showed very distinctive and differential herbivory. For instance, at one site (Fig. 1), one clone was large, and consisted of trees of varying ages, suggesting greater resistance to herbivory and more recent recruitment. A second clone located nearby on what appeared to be a similar site comprises only large, older trees described as "decadent" (R. Campbell, Jr, US Forest Service, personal communication). This decadent clone showed little evidence of current or recent successful sprouting of aspen saplings. 


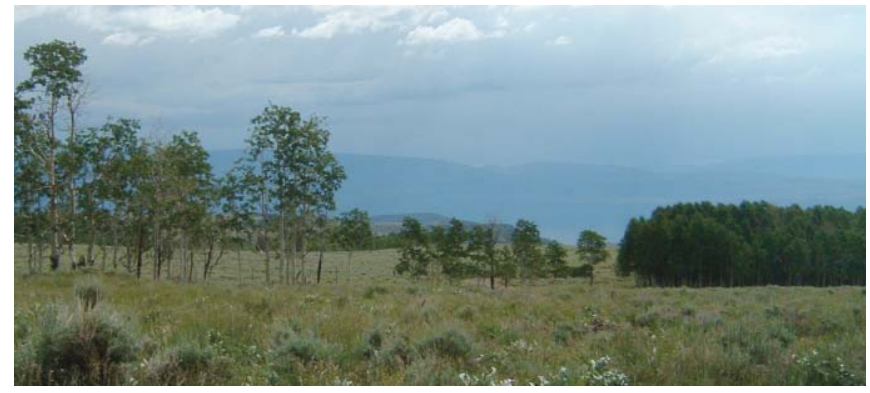

Figure 1. Aspen clones on Monroe Mountain, north of Koosharem, Utah. Note the differences between the clones in the left and center of the photograph compared with the clone in the lower right. Photo by Sarah C. Brown.

Variation in susceptibility to herbivory in aspen is not surprising, given that aspen are also highly variable in growth rate, physiology, disease resistance, and most famously, fall color. Although much less well-known, aspen chemical defenses also vary widely among clones ${ }^{16}$ and likely influence mammalian herbivory. To date, very little work has been published examining the effects of aspen defensive chemistry on large mammalian herbivores, but the limited evidence suggests that aspen defensive chemicals are important determinants of elk herbivory. ${ }^{12}$

\section{Elk Herbivory and Plant Chemistry}

Elk food choice is influenced by both availability and quality of plant material. ${ }^{8}$ Quality is determined by levels of nutrients (e.g., protein), structural components (e.g., fiber), and anti-herbivore defensive chemicals. Defensive chemicals in aspen include condensed tannins and the toxic, bitter phenolic glycosides, salicortin and tremulacin. Tannins reduce the ability of mule deer (Odocoileus hemionus) and sheep (Ovis aries) to digest their food ${ }^{17}$ and influence beaver (Castor canadensis) food choice. ${ }^{18}$ Phenolic glycoside levels can significantly alter food choice by ungulates. For example, aspen with relatively low phenolic glycoside concentrations were preferentially consumed by elk compared with those with higher concentrations. ${ }^{12}$

Based on observations of differential herbivory among aspen clones and knowledge of the effects of defensive chemicals on mammal food choice, ${ }^{17-19}$ we performed a series of feeding trials with captive bull elk to determine if they would discriminate among aspen clones. If elk prefer some aspen clones but avoid others, then perhaps not all aspen are "doomed."

\section{Elk Feeding Trials}

For the five replicate feeding trials, we chose aspen clones that we knew (from previous work) had a range of defensive chemical concentrations. For $1 \mathrm{wk}$ prior to the feeding trials, elk were acclimated to our presence and to feeding on aspen. In all the trials, we used the same three captive bull elk individuals ( $3 \mathrm{yr}$ old). The animals were confined in a 5-acre pen at the Kane Valley Elk Ranch in Ephraim, Utah.

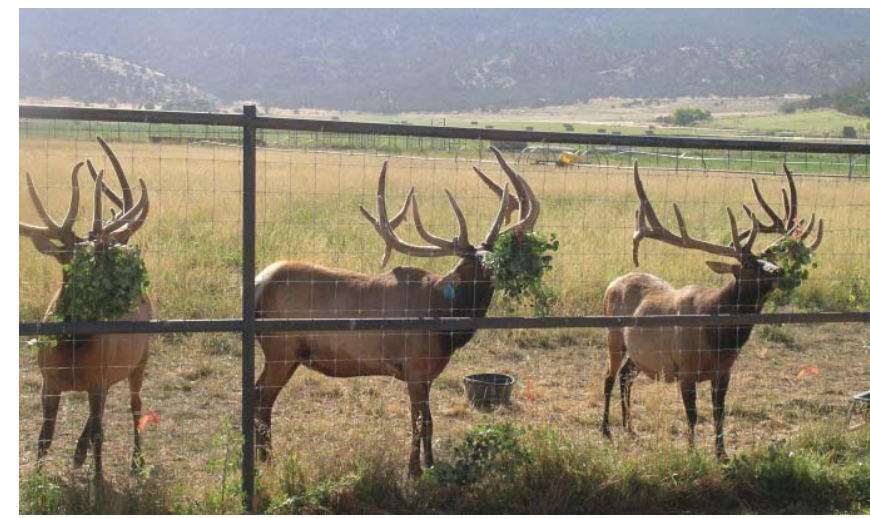

Figure 2. Each feeding trial was conducted similarly with five aspen clones and three bull elk. The aspen bundles were tied to the fence and the elk were allowed to feed. After feeding, all remaining aspen material was collected and returned to the lab for weighing. All trials were conducted at Kane Valley Elk Ranch in Ephraim, Utah. Photo by Stuart Wooley.

The forage growing in the pen (mainly grass) was irrigated as needed and was available ad libitum through the summer (Fig. 2). The elk also received a small portion of grain each morning.

The aspen material for the feeding trials was collected at two locations in the Manti-LaSal National Forest above Ephraim, Utah. Aspen branches were cut from trees $>8 \mathrm{yr}$ old from a height in the tree canopy accessible to elk $(<2 \mathrm{~m}$ [6.5 feet]). Branches from each clone were kept in separate 18-L (5-gallon) buckets with the cut branch tips placed in water. We transported the material to the Utah Division of Wildlife Resources, Great Basin Research Center, in Ephraim, Utah. During the trials, the plant material was kept in the buckets with sufficient water to maintain freshness and stored in a walk-in refrigerator at $4^{\circ} \mathrm{C}$ $\left(39^{\circ} \mathrm{F}\right)$.

For each of five replicate feeding trials (Fig. 2) we weighed approximately $1 \mathrm{~kg}$ ( 2.2 pounds) of browse material (branches with leaves) from each aspen clone. Immediately before each feeding trial, we measured the beginning weight $(\mathrm{g})$, number of short shoots, number of leaves on each short shoot, total number of leaves, and fresh weight $(\mathrm{g})$ of a subset of leaves from each clone bundle on each day. We also determined leaf dry weight from a subset of leaves from each clone in each trial. We calculated total leaf weight from the measurements of leaf number and weight. Bundles were tied tightly to the fence inside the pen to prevent the elk from tearing them off of the fence. To eliminate the effect of height on choice, ${ }^{19}$ all aspen bundles were presented at equal heights (approximately $1.6 \mathrm{~m}$ [ 5 feet $]$ ) in both the trial and acclimation periods.

In each trial, the elk were allowed to choose among the five bundles (one bundle from each aspen clone) placed 2-2.5 m (6.5-8 feet) apart. We observed elk feeding for the duration of the feeding bout (14-18 min) during each of 
the five trials. Trials occurred on each day for five consecutive days. The position of bundles was changed from day to day, so the most preferred clones were not always in the same location.

After the elk finished eating, we retrieved and weighed all of the remaining material. For each bundle on each day, we calculated total consumption (beginning bundle weight - remaining bundle weight $[\mathrm{g}]$ ), which included both leaf and woody tissue, and leaf consumption (beginning leaf weight-ending leaf weight $[\mathrm{g}]$ ), which included only leaf tissue. During each feeding trial, we placed a $1-\mathrm{kg}$ (2.2-pound) bundle of aspen branches (one branch from each experimental clone) on the fence but out of reach of the elk. These branches served as a control for water loss in the experimental bundles during the trial. The water loss due to air-drying was subtracted from the consumption values prior to statistical analysis. We also collected representative leaves from each clone for condensed tannin and phenolic glycoside analysis. ${ }^{20}$

We performed several statistical analyses to determine 1) whether elk consistently chose among aspen clones, and 2) the chemical basis of any demonstrated preferences. We first performed a stepwise regression to determine the relationship of total consumption to characteristics of aspen that might influence elk preference. The characteristics included in the model were beginning bundle weight $(\mathrm{g})$, number of short shoots, total leaf number, total leaf weight (g; estimated for each clone), trial, and clone. Defensive chemistry was not included in the stepwise regression because chemistry data were collected only on the last trial date. Aspen clone was the most significant variable in the regression analysis explaining elk preference. Second, we performed two simple regression analyses to determine the relationship between aspen chemistry and elk herbivory. In the first analysis, total consumption was regressed against the foliar concentrations of defensive chemicals (tannin, salicortin, tremulacin, and total phenolic glycosides [salicortin + tremulacin]). The second analysis was similar, with leaf consumption regressed against foliar concentration of defensive chemicals.

\section{Elk Choice and Aspen Chemistry}

When given a choice among different aspen clones, elk preferred to feed on some clones over others, indicating that all aspen clones are not equally preferred as browse (Fig. 3). The aspen clones preferred by elk were those with relatively lower phenolic glycoside concentrations (Table 1). When phenolic glycoside concentrations were as high as $20 \%$ the elk consumed more than $30 \%$ less aspen than when phenolic glycoside concentrations were below 15\%. Elk consistently preferred certain aspen clones, whether measured by total consumption (Fig. 4a) or by leaf consumption (Fig. 4b). The negative relationship between consumption and phenolic glycoside concentration was significant, however, only in the latter case (Table 1). The pronounced reduction in

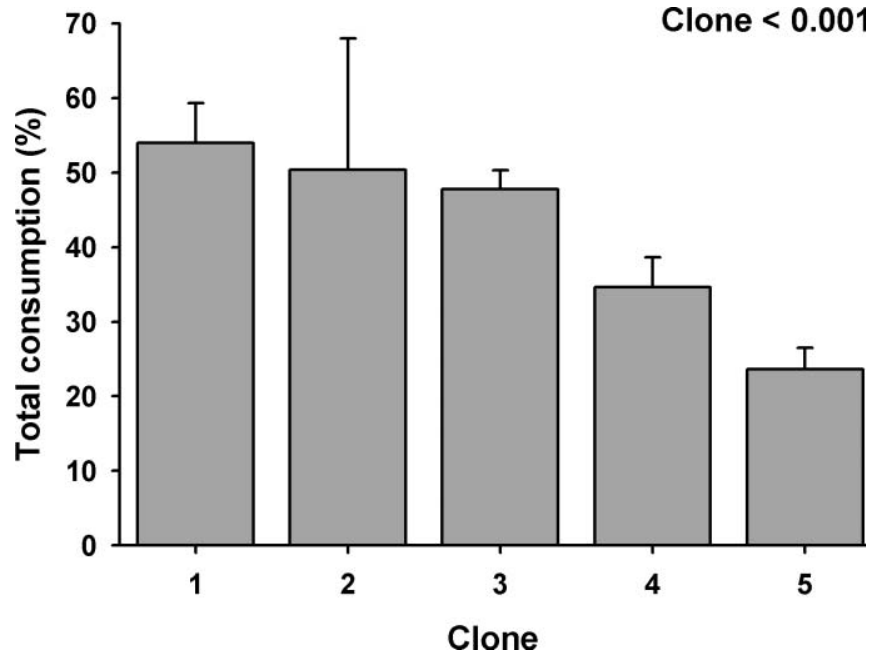

Figure 3. Total consumption (percent of total bundle weight eaten) among aspen clones. Bars represent the mean (+ $1 \mathrm{SE})$ consumption of aspen bundles from each clone over five sequential feeding trials.
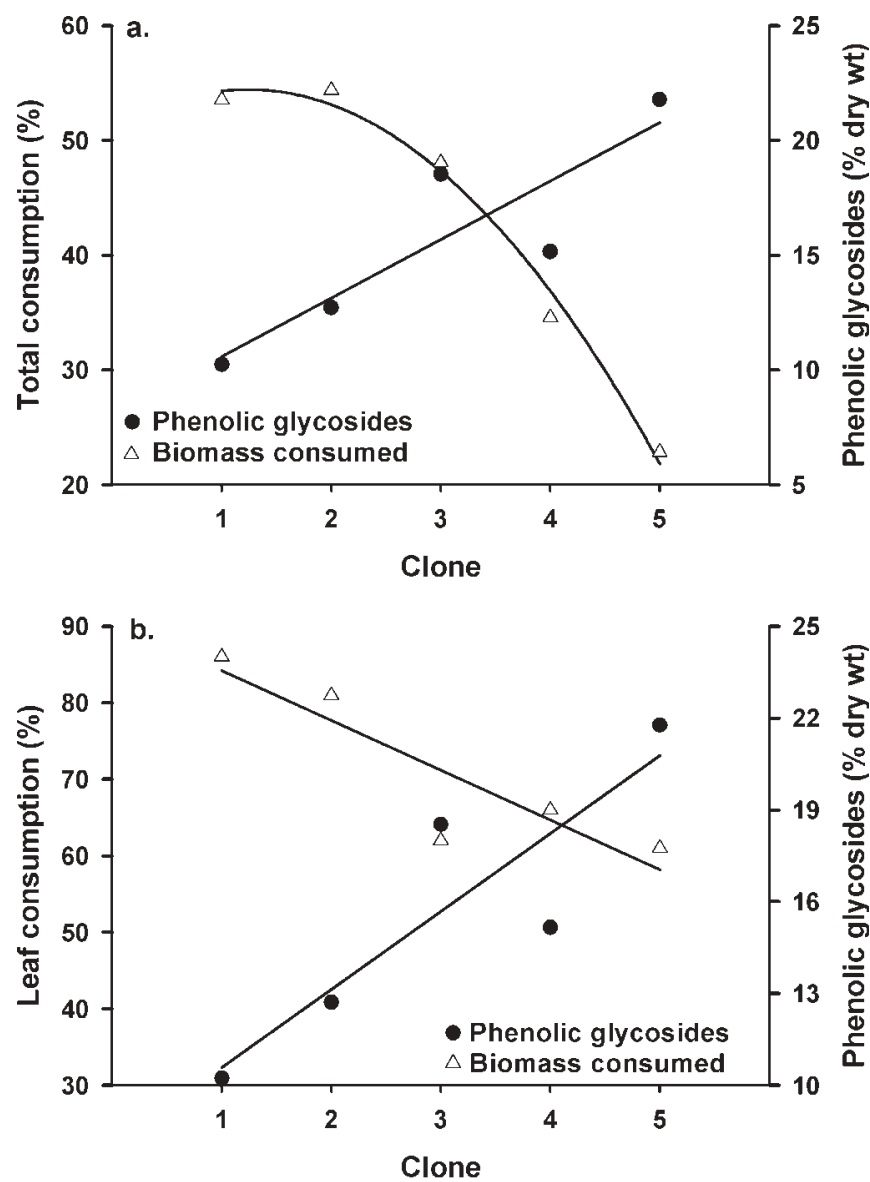

Figure 4. a, Total consumption (percent of total bundle weight eaten) of the aspen bundles in relation to the concentration of the foliar phenolic glycosides among aspen clones. b, Leaf consumption (percent of total leaf weight eaten) of aspen bundles in relation to the concentration of foliar phenolic glycosides among aspen clones. 
Table 1. Simple linear regression results explaining the relationship of total consumption (g) or leaf consumption $(g)$ in relation to the foliar concentration of phenolic glycosides and condensed tannins

\begin{tabular}{|l|c|c|c|c|}
\hline \multirow{2}{*}{} & \multicolumn{2}{|c|}{ Total consumption } & \multicolumn{2}{c|}{ Leaf consumption } \\
\hline Salicortin & $\boldsymbol{r}$ & $\boldsymbol{P}$ & $\boldsymbol{r}$ \\
\hline Tremulacin & 0.68 & 0.207 & 0.95 & 0.014 \\
\hline Total phenolic glycosides & 0.61 & 0.279 & 0.89 & 0.045 \\
\hline Condensed tannins & 0.65 & 0.235 & 0.92 & 0.024 \\
\hline
\end{tabular}

consumption as phenolic glycoside concentrations increased suggests that they indeed defend aspen against elk herbivory. The pattern of reduction shown by the lines in Fig. 4 illustrates that near a certain threshold phenolic glycoside concentration (approximately 16\%-17\%), elk consumption markedly decreases. In contrast, tannins did not influence elk preference among aspen clones (Table 1), most likely because they were at very low concentrations $(<2 \%)$. An additional reason might be that elk and other large mammals produce proteins in their saliva that bind tannins and thereby reduce their negative effects. ${ }^{17}$

\section{Implications for Aspen Ecology}

Results of this study indicate that when given a choice, elk select among aspen clones based on foliar levels of phenolic glycosides. Several implications follow from these results. If large mammal (e.g., elk, cattle) herbivory is a primary cause of aspen decline in the west, as has been suggested by many investigators, ${ }^{1,2,6,7}$ we suggest that a major "natural" selection process is ongoing. If ungulate browsers preferentially select aspen with low phenolic glycoside levels, then repeated browsing will lead to reduced growth and regeneration and potential loss of those aspen clones. The remaining aspen clones will be relatively more resistant to elk herbivory (e.g., higher phenolic glycosides). Ultimately, the result of intense mammalian herbivory will be an eventual change in aspen population structure. Population-level changes in herbivore resistance as a result of mammalian herbivory have been documented in aspen-beaver ${ }^{21,22}$ and cottonwood-beaver systems. ${ }^{18}$ In some western locations, this same process has already been documented in an aspen-elk system. Bailey et al. ${ }^{12}$ showed that over a $4-y r$ period, elk selectively removed aspen saplings with relatively low concentrations of phenolic glycosides, thereby altering the chemical composition of the aspen forest (i.e., increased frequency of trees with high phenolic glycosides). Because of the change in characteristics of the aspen forest, interactions of aspen with other community members are likely to change. ${ }^{12}$

At first glance, having a more highly defended aspen population seems advantageous because the trees could be more resistant to elk herbivory. However, the production of phenolic glycosides comes at a cost to aspen growth. ${ }^{23}$ Therefore, elk herbivory could present a double blow to aspen regeneration in the West. By increasing the proportion of high phenolic glycoside trees in the population, elk could simultaneously be selecting for slow-growing trees. As a consequence, the aspen remaining in the population will generally be less palatable, but also grow more slowly. Slow-growing aspen will take longer to reach the 2-m stature required to escape elk herbivory. ${ }^{1,2,6}$ Aspen recruitment ("suckering") or regrowth following herbivory could also be slower.

In areas where elk populations are so large as to consume virtually all regenerating aspen, ${ }^{1}$ high concentrations of defensive chemicals do not protect aspen from herbivory (even poor food is better than none). Our data tend to support this notion, because even with very high phenolic glycosides ( $>20 \%$ ), elk still consumed more than $20 \%$ of the aspen given to them. Thus, application of these results might be appropriate only to areas of low to moderate elk population density.

Solutions to slow or stop aspen decline, such as restoring historical fire frequency, adjusting livestock grazing practices, and reducing elk population size ${ }^{11}$ by introducing carnivores (wolves) $)^{1}$ are highly controversial. Although implementing these practices might help reduce aspen decline, major conflicts with human recreation, housing, livelihoods, and long-standing traditions hamper their implementation. Furthermore, because the issues are complex, a single solution is unlikely to reduce aspen decline across the western United States. Therefore, making use of all available tools, including understanding aspects of aspen chemical ecology and physiology, might improve our ability to devise successful management or restoration strategies.

\section{Acknowledgments}

We thank Mr. Ron Green of Kane Valley Elk Ranch for allowing us to conduct research with his captive elk. We also thank Alan Saltzman, Tana Pickett, Nalisa Bradley, Alison Whitaker, and Trisha, Nathan, Emilie, and Tylek Bradley for field assistance. Chad Shorter and Chris Habeck 
provided comments on an earlier draft. This work was funded by a NSF-IRCEB grant (0078280) and NSFFIBR grant (0425908) and conducted in part at the Great Basin Research Center in Ephraim, Utah where funding was provided through a Federal Aid to Wildlife Grant W-82-R.

\section{References}

1. White, C. A., C. E. Olmsted, and C. E. Kay. 1998. Aspen, elk, and fire in the Rocky Mountain national parks of North America. Wildlife Society Bulletin 26:449-462.

2. Ripple, W. J., and R. L. Beschta. 2005. Willow thickets protect young aspen from elk browsing after wolf reintroduction. Western North American Naturalist 65:118-122.

3. Romme, W. H., M. G. Turner, G. A. Tuskan, and R. A. REED. 2005. Establishment, persistence, and growth of aspen (Populus tremuloides) seedlings in Yellowstone National Park. Ecology 86:404-418.

4. Mueggler, W. F. 1989. Age distribution and reproduction of intermountain aspen stands. Western Journal of Applied Forestry 4:41-45.

5. Romme, W. H., M. G. Turner, L. L. Wallace, and J. S. Walker. 1995. Aspen, elk, and fire in northern Yellowstone National Park. Ecology 76:2097-2106.

6. Kay, C. E., And D. L. Bartos. 2000. Ungulate herbivory on Utah aspen: assessment of long-term exclosures. Journal of Range Management 53:145-153.

7. Walker, S. C. 1993. Effects of cattle and big game on secondary succession of aspen-conifer understory following fire [thesis]. Provo, UT, USA: Brigham Young University. 27 p.

8. Beck, J. L., J. T. Flinders, D. R. Nelson, C. L. Clyde, H. D. Smith, And J. Hardin. 1996. Elk and domestic sheep interactions in a North-Central Utah Aspen ecosystem. USDA Forest Service Intermountain Research Station Research Paper INT-RP-491. $114 \mathrm{p}$.

9. Kay, C. E. 1997. Is aspen doomed? Journal of Forestry 95: 4-11.

10. Baker, B. W., J. A. Munroe, and A. E. Hessl. 1997. The effects of elk on aspen in the winter range in Rocky Mountain National Park. Ecography 20:155-165.

11. Weisberg, P. J., and M. B. Coughenour. 2003. Modelbased assessment of aspen responses to elk herbivory in Rocky Mountain National Park, USA. Environmental Management 32:152-169.

12. Bailey, J. K., J. A. Schweitzer, B. J. Rehill, D. J. Irschick, T. G. Whitham, and R. L. Lindroth. 2007. Rapid shifts in the chemical composition of aspen forests: an introduced herbivore as an agent of natural selection. Biological Invasions 9:715-722.

13. Ripple, W. J., and R. L. Beschta. 2006. Linking wolves to willows via risk-sensitive foraging by ungulates in the northern Yellowstone ecosystem. Forest Ecology and Management 230:96-106.

14. Singer, F. J., L. C. Mark, and R. C. Cates. 1994. Ungulate herbivory of willows on Yellowstone's northern winter range. Journal of Range Management 47:435-443.

15. Singer, F. J., L. C. Zeigenfuss, R. G. Cates, and D. T. BARnETT. 1998. Elk, multiple factors, and persistence of willows in national parks. Wildlife Society Bulletin 26:419-428.

16. Lindroth, R. L., and S. Y. Hwang. 1996. Clonal variation in foliar chemistry of quaking aspen (Populus tremuloides Michx.). Biochemical Systematics and Ecology 24:357-364.

17. Robbins, C. T., A. E. Hagerman, P. J. Austin, C. McArthur, and T. A. Hanley. 1991. Variation in mammalian physiological-responses to a condensed tannin and its ecological implications. Journal of Mammalogy 72:480-486.

18. Bailey, J. K., J. A. Schweitzer, B. J. Rehill, R. L. Lindroth, G. D. Martinsen, and T. G. Whitham. 2004. Beavers as molecular geneticists: a genetic basis to the foraging of an ecosystem engineer. Ecology 85:603-608.

19. Duncan, A. J., S. E. Hartley, M. Thurlow, S. Young, and B. W. Staines. 2001. Clonal variation in monoterpene concentrations in Sitka spruce (Picea sitchensis) saplings and its effect on their susceptibility to browsing damage by red deer (Cervus elaphus). Forest Ecology and Management 148:259-269.

20. Lindroth, R. L., K. K. Kinney, and C. L. Platz. 1993. Responses of deciduous trees to elevated atmospheric $\mathrm{CO}_{2}$ : productivity, phytochemistry, and insect performance. Ecology 74:763-777.

21. Basey, J. M., S. H. Jenkins, and P. E. Busher. 1988. Optimal central-place foraging by beavers: tree-size selection in relation to defensive chemicals of quaking aspen. Oecologia 76:278-282.

22. Basey, J. M., S. H. Jenkins, and G. C. Miller. 1990. Food selection by beavers in relation to inducible defenses of Populus tremuloides. Oikos 59:57-62.

23. Osier, T. L., and R. L. Lindroth. 2006. Genotype and environment determine allocation to and costs of resistance in quaking aspen. Oecologia 148:293-303.

Authors are Post-doctoral Associate, wooley@biology.csustan.edu (Wooley) and Professor (Lindroth), Dept of Entomology, 1630 Linden Drive, University of Wisconsin, Madison, WI 53706, USA; Habitat Manager, Utah Division of Wildlife Resources, Northern Region, 515 East 5300 South, Ogden, UT 84405, USA (Walker); and Director, Great Basin Research Center, Division of Wildlife Resources, 494 West 100 South, Ephraim, UT 84627, USA (Vernon). Current address for Wooley: Assistant Professor, California State University, Dept of Biological Sciences, 1 University Circle, Turlock, CA 95382, USA. 
Physiological and Morphological

Characterization of Basalt Milkvetch

(Astragalus filipes): Basis for Plant

Improvement

Kishor Bhattarai, Douglas A. Johnson, Thomas A. Jones, Kevin J. Connors, and Dale R. Gardner

Few legumes from North America are commercially available for use on semiarid rangelands of the western United States. Basalt milkvetch (Astragalus filipes) is a legume that is widely distributed in western North America and holds promise for revegetation, reclamation, and restoration. Seeds from 67 locations throughout six western states were collected, seedlings were transplanted to two sites in northern Utah, and plants were evaluated for various physiological and morphological characteristics. Results provide important data for identifying basalt milkvetch collections that have the greatest potential for use on degraded rangelands.
Perceptions of Texas Landowners Regarding Fire and Its Use

Urs P. Kreuter, J. Brad Woodard, Charles A. Taylor, and W. Richard Teague

Periodic fire is a historical element of many rangelands, but landowners are frequently reluctant to burn their land because they perceive it to be a dangerous or wasteful practice. We report the results of a survey evaluating perceptions of fire use for 785 landowners in six Texas counties. Reasons respondents did not apply fire included lack of resources, assistance with burn plan development, and legal concerns, while members of the Edwards Plateau Prescribed Burning Association viewed prescribed fire more positively. Our study suggests that the application of prescribed fire on privately owned land could be increased through the formation of prescribed burning associations.

\section{Erratum}

\section{Wooley, S. C., S. Walker, J. Vernon, and R. L. Lindroth. 2008. Aspen Decline, Aspen Chemistry, and Elk Herbivory: Are They Linked? Rangelands 30(1):17-21.}

In this article, $r$ values in Table 1 should be preceded by negative signs. The primary author regrets the error. The corrected table is shown below.

Table 1. Simple linear regression results explaining the relationship of total consumption (g) or leaf consumption (g) in relation to the foliar concentration of phenolic glycosides and condensed tannins

\begin{tabular}{|l|c|c|c|c|}
\hline & \multicolumn{2}{|c|}{ Total consumption } & \multicolumn{2}{c|}{ Leaf consumption } \\
\hline Salicortin & $\boldsymbol{r}$ & $\boldsymbol{P}$ & $\boldsymbol{r}$ \\
\hline Tremulacin & -0.68 & 0.207 & -0.95 & 0.014 \\
\hline Total phenolic glycosides* & -0.61 & 0.279 & -0.89 & 0.045 \\
\hline Condensed tannins & -0.65 & 0.235 & -0.92 & 0.024 \\
\hline *Total phenolic glycosides are the sum of the concentration of salicortin and tremulacin. & 0.375 \\
\hline
\end{tabular}

